\title{
THE GEORGIAN PERIOD OF THE FILMMAKER OTAR IOSELIANI
}

DOI: https://doi.org/10.52603/arta.2021.30-2.11

Creația regizorului Otar Ioseliani are un rol semnificativ în evoluţia artei cinematografice georgiene. Începând cu anii 冈50, Ioseliani activează în RSS Georgia, iar din anii 囚80, grație unor circumstanțe ideologice, își continuă activitatea sa de cineast în Franța.

Ioseliani s-a impus printr-un stil aparte în depistarea și exprimarea cinematografică a părților negative ale vieții cotidiene. De aceea majoritatea filmelor sale nu erau acceptate de critica de film sovietică, aclamându-le ca lucrări negative, ce nu se potriveau realității și stilului sovietic de viață. Acele lucrări corespundeau mai mult condițiilor realismului critic decât realismului socialist - dogma regimului totalitar.

Drept argumente la aceste idei vor servi analiza (tematică, fondul ideatic, modalitatea de expresie cinematografică ș.a.) filmelor lui Otar Ioseliani din perioada georgiană, începând cu lucrarea de licență Acuarela (1958) și continuând cu filmele devenite cunoscute de publicul larg: Noiembrie, Ultima frunză, Pastorala, A fost odată o mierlă.

Cuvinte-cheie: Otar Ioseliani, perioada georgiană, realism socialist, stil regizoral, expresie cinematografică.

\section{Summary \\ The Georgian period of the filmmaker Otar Ioseliani}

The creation of the film director Otar Ioseliani has a significant role in the evolution of Georgian cinematographic art. Since the 1950s, Ioseliani had been active in RSS Georgia, and since the 1980s, thanks to ideological circumstances, he continued his work as a filmmaker in France.

Ioseliani imposed himself through a special style in the detection and cinematic expression of the negative parts of everyday life. That is why most of his films were not accepted by Soviet film critics, acclaiming them as negative works that did not fit the Soviet reality and lifestyle. Those works corresponded more to the conditions of critical realism than to socialist realism - the dogma of the totalitarian regime.

As arguments for these ideas will serve the analysis (thematic, ideational background, cinematic expression, etc.) of Otar Ioseliani's films from the Georgian period, starting with the bachelor's thesis Watercolor (1958) and continuing with the films that became known to the general public: November, The Last Leaf, Pastoral, Once Upon a Time there was a Blackbird.

Keywords: Otar Ioseliani, Georgian period, socialist realism, directorial style, cinematic expression.

One of the greatest Georgian filmmakers Otar Ioseliani is a very interesting and original artist who is placed on a very special level in the history of Georgian cinema. His creative work may be divided into the Georgian period and French period, because beginning in the 50s in Georgia, he continued working in France since the 80 s. Otar has a particular skill in finding the critical sides of everyday life and presenting them to the auditorium for thinking, recycling and making decisions. Of course, many film critics in the Soviet Union (when Georgia was one of the Soviet republics) did not like most of his Georgian period films, acclaiming them as negative works, which were not suitable to the Soviet reality and lifestyle. Yet, if we analyze them deeply, we could discover that they were good examples of critical realism (not socialist realism) and the-director wanted to tell his attitude through his main characters.

Otar Ioseliani is a representative of the new generation of Georgian filmmakers. Most of them shot their main fiction (short and feature) films in the 60s, that's why their name in the history of Georgian cinema is not a "New Wave" but "The Generation of the 60s". The brothers Eldar Shengelaya and Giorgi Shengelaya, Lana Ghoghoberidze, Merab Kokochashvili, Tamaz Meliava, Mikheil Kobakhidze, etc. are among them. They 


\section{Arta cinematografică şi televiziunea}

graduated from the Moscow State Institute of Cinematography (VGIK). Some of them started by making documentaries and turned to fiction films. Their works were different from the films made by their predecessors and frequently were a subject of debates. Influenced by contemporary Italian neorealist and French new wave films, the younger generation brought about new themes, symbols, documentary manners, emotions, ironic attitude to things and phenomena and the new world with different situations and beliefs. Thus, they fulfilled the mission of transferring Georgian cinema to a new dimension. They expressed their positions in their films and proved that Georgian cinema was developing rapidly [2, p. 156].

"The Generation of the 60s" was mentioned in literature and in the other fields of the art as well. Those were representatives of the new generations. Part of them was called dissidents because their positions greatly differed from the Soviet official ideology. In addition to them, there were many others in literature and arts, the conformists who could adapt to the political course of the government and the communist party of the USSR.

The censorship in the Soviet Union always worked. Of course, it existed in the film industry too. This means all sorts of control from the script departments of the film studios up to high state censorship. It is noteworthy that Joseph Stalin himself was the number one censor. He read the scripts himself, made corrections there, came up with movie titles, and, in some cases, had meetings with film directors, with the leaderships of the film studios, or the state film committee to discuss the problematic issues of Soviet filmmaking, and so on. There were cases when in the 30s-50s some films were banned and were shelved for uncertain time. Other films had gone through the toughest censorship and, if someone could find any anti-state or non-suitable to the ideology things in them, the making of that film was stopped and its scriptwriter and (or) director could be jailed.

Since 1952 after Stalin's death, the situation softened. This period, which continued for approximately 11-12 years, was named the "Epoch of Thaw". The representatives of literature and art received a little freedom and they tried new experiments, expressed a new sight to the things and events, used innovative techniques, etc. Indeed, most Soviet films were made by means of socialistic realism methods but there also appeared some films, in which the critical attitude to con- temporary life or the recent past was presented. The Georgian film underwent the same evolution as well, but since the second half of the 60 s the censorship became harsher and the practice of banning films repeated again. Otar Ioseliani was a victim of such censorship several times, because he tried to say and screen his position critically and did not want to show the beautified reality.

The period of Georgian film history after World War II is often referred to as an "Epoch of a Low Movie Numbers". In the years 1946-1952, Tbilisi Film Studio issued only eight fiction films. The country was recovering from the post-war crisis: the destroyed agriculture and industry were being restored and most of the financial resources were allocated for this purpose. The objective of the filmmakers was to make realistic contemporary films, so that the audience was impressed by the decent behavior of the main characters. Certainly, the method of socialistic realism was dominant in films (and not only in films but in all other art fields and literature) and the government of the USSR demanded from artists and writers to include samples of that realism in their works.

In 1953, "Tbilisi Film Studio" was turned into "The Georgian Film Studio" ("Gruzia Film"). Parallel to the organizational changes, ways of improvement of the film production were outlined. New convincing manners of narration, realistic themes, and innovative forms were the main characteristic features of films made in this period. The directors, employed at the studio, started working with great enthusiasm and new energy. They were skilled in scriptwriting, film direction, and photography. Thus, the films of that period were to remain in the memories of the audience and, at the same time, they expressed the civic position of the authors. Naturally, the reforms required corresponding professional and psychological preparation. The lack of the above-mentioned affected the number of films.

In 1953, the Soviet Ministry of Culture was ordered to deal with film-related issues. This state organization urged filmmakers to submit new scripts. The best script would be financed and produced. Besides, it was planned to publish a collection of scripts of the most successful Georgian films. However, for certain reasons, this noble cause was hampered.

The authorities paid great attention to the filmmakers who brought fame to the Georgian cinema. In this period, about 300 Georgian film- 


\section{Arta cinematografică şi televiziunea}

makers were awarded prizes and medals. Some of them even received the title of Honorable Worker of Art. The following stage of development of Georgian cinema was fruitful both concerning the quality and the quantity of films. Some of the films made in this period are of special cinematographic value and have interesting narratives.

In 1958, the Film Chronicles Department of "Georgian Film Studio" was restructured into the Studio of Documentary-Chronicle and Popular Science Films. This enhanced the possibilities of the genre and attracted representatives of the young generation of documentary filmmakers. The studio worked fruitfully in this period. Alongside with experienced directors, representatives of the younger generation created numerous interesting films on new themes. These films were outstanding for their novelty, manner of direction, individuality, and originality.

The film-related issues were administered by the Georgian State Committee of Cinematography. Its function was to manage the planning, financing, distribution, and improvement of the artistic quality of the films. The Georgian Union of Filmmakers also worked fruitfully, organizing premieres of Georgian films, screenings of foreign films, anniversaries, creative meetings, forums, conferences, etc. Another organization was the local Bureau of Film Propaganda, which held interesting lectures and screenings. By the way, Otar Ioseliani was one of the lecturers who collaborated with that bureau and delivered lectures about filmmaking and editing to various Georgian organizations. This was his additional work.

In the second half of the 60s, the main focus of the Georgian filmmakers was the deep analysis of human nature and the search for positive human features. The majority of the best Georgian films were made in this period. Naturally, low-quality cliché films were also made, although they were also dedicated to important themes. Since that decade, an expression appeared in cinematic criticism "the phenomenon of Georgian cinema" [5, pp. 211-212].

In the 70s, Georgian films bore the print of the tendencies of the 60s but also followed the trends of earlier decades. The mixture of old and new trends was a characteristic feature of the films of the 70s and a sign of artistic development.

Otar Ioseliani was born on February 2, 1934, in Tbilisi (the capital of Georgia). Since his childhood years, he fell in love with classical music; simultaneously with secondary school he studied at the specialized music school in a class of fortepiano. This is the main reason why so much and various music is played in his films. It is a peculiar nostalgia for the above-mentioned period of his life. After that in 1953, he went to Moscow University and became a student of the Faculty of Mechanics and Mathematics. He spent there only three years, left this university and continued to study at VGIK, in the group of the well-known Soviet film director and professor Alexandr Dovjenko.

Otar Ioseliani's very first work is the short fiction film "The Watercolor" (1958), based on the motifs of Alexander Grin's short story. It was his bachelor's thesis in the third year of studies. He shot it in Russia and presented it to VGIK. It should be noted that the cameraman of this film was another student of the same film school Alexandre Rekhviashvili, a person who subsequently became a talented cameraman and film director. Certainly, this film had not any serious meaning in terms of mastery because at that time Ioseliani was mastering the nuances of film directing, he learned, learned, learned. It was like a peculiar exercise for him: how to create a composition, how to shoot from various perspectives and how to deliver his opinions and senses to the filmgoers. His film directing style was not refined yet and he often spoke that there were such moments in art, which in often cases were different from reality. The plot of the film is very ironic; it is about a poor family. The husband is an alcoholic and the wife is a laundress. The husband usually spends his wife's money for buying alcoholic beverages. Once the husband steals money from his wife and runs away. The wife chases after him and both find themselves in the exhibition hall. They discover a picture of a house made in watercolors, which seems very cozy and attractive than it actually is. One of the guides (this character is played by Otar Ioseliani) notes that great warmth is coming from this picture and points that decent and noble people live in this house, who work honestly, have many children and are very happy. Of course, it is only that guide's assumption and he does not know who lives in that house. This film shows the controversy between socialist realism and acute realism, the desirable imagination, and the sad reality.

The next film, which also was a student work, is dedicated to the interesting person, florist and artist-decorator, the over-eighty-years-old 


\section{Arta cinematografică şi televiziunea}

Mikheil (Mikha) Mamulashvili, who was a famous man in Georgia for his beautiful and unique garden. The name of the film is "Sapovnela" (1959). Sapovnela is a Georgian name of a low-growing annual plant with brightly colored flowers. The script of this film had been in the Georgian Studio of Documentary-Chronicle and Popular Science Films for a long time and nobody wanted to shoot it. One day a young man, a VGIK student Otar Ioseliani took that script and made not a documentary, as the studio leadership wanted, but a fiction-documentary film, a kind of parable about the relation between man and nature. The director always declared, that "nature creatively charges a person and allows creating polyphonic folklore songs, samples of architecture and fine arts" [1, p. 34]. Otar Ioseliani, being also the musical director of this film, used both Georgian national music and classical music in it. From directorial point of view, this film needed no text, but the film studio did not inform the author about it and included extensive text, which was not suitable to the plot. In this work, Ioseliani continued his training concerning frame composition, editing, use of soundtracks. At that time, he paid serious attention to the noises in a film, which were to help him in his future creative work. "The film acquires the signs of the fable related to nature's eternal rotation, the bilateralism of results after the human being intervenes in its canons" [6, p. 179].

After that Otar Ioseliani decided to shoot his diploma film for VGIK. As a brave man, who always told the truth, he made the short fiction film "April" (1962) and marched against false values. In this work, he proved the name of master of storyboarding - everything was written and drawn with mathematical accuracy. The plot of this film is a melodramatic story about a couple of very happy lovers. Having received a flat, they bought furniture like the one of the other neighbors and it will be the cause for their separation. Finally, they both understand the reason for alienation and throw the furniture out of the window. Ioseliani was saying: "I am mostly afraid of falsehood in art. It is not easy to reach such level of honesty and courage which helps the artist's conception to be closer to the result without falsehood, flattery and loss. Loud opinion losses a lot. It subconsciously crosses several inertial psychological barriers and it frees flow changes. That's why in my films I avoid intonation, which proves the uncertainty of what happened" [6, p. 182].
This film also encountered problems - it was cut, remade, reduced, without telling anything to the author, and then banned. Ioseliani could not submit the diploma work to the examination commission of VGIK. The film was shelved. After some years, the studio authorities allowed Otar to edit this film again but he discovered that only some parts survived. Nevertheless, he edited these parts but many of the author's ideas had been lost.

Otar Ioseliani had never opposed the state system but only exposed the disadvantages. Being a talented artist, he had many envious people around. He did not pay attention to them and continued to find interesting materials for shooting the next film. He liked to say: "a work of art, among other things, is a piece of paper written by us about our own lives among people. And while studying life, generations are flipping through an art book, each page of which represents the life of an artist" [1, p. 56].

At first, he wanted to make a film about fishermen and, for this reason, he began to work on a fishing ship. Then he went to Rustavi Metallurgical Plant (near Tbilisi) and worked there as a simple worker. This experience gave him the idea of shooting the documentary about his coworkers "The Cast Iron". He did it in 1964 in Moscow. The famous Soviet filmmaker Grigory Chukhray, who was one of the members of the examination commission of VGIK, liked this film and wrote a positive review about this work. Later other members of that commission agreed with him and gave the film a high rating. Otar Ioseliani received the diploma of filmmaker.

"The Cast Iron" is a realistic film about the plant workers, their everyday work, shot attractively, in full compliance with the documentary style. There are many noises in the film - different voices, alongside with music performed by a violin. Of course, the local censorship did not like such cruel and hard reality and because of it, the film studio made only a few copies of the film, which were screened in a few movie theaters.

Otar Iosseliani's first full-length fiction film was "Fallen Leaves" ("Giorgobistve", 1966). This last word - "Giorgobistve", according to the old Georgian calendar means the month of November, the time of wine-making; local peasants make wine out of grapes. This film is a very unique work, in which the director expressed one particular citizen's protest against the unjust and corrupt system. This injustice is happening in one 


\section{Arta cinematografică şi televiziunea}

of the wine-making factories of Georgia where they have the "tradition" of sometimes making bad wine and distributing it. All the employees of the winery practice this tradition of falsifying the product and no one questions it. Meanwhile, Niko, who is a lead character, wine technology graduate from the agricultural university gets assigned to the winery and after a while discovers this counterfeit. He is stunned by such dishonest engagement, the indifference of employees and superiors, and decides to go against it, not let them dilute the natural quality of the wine. Despite everyone telling him that his efforts are in vain, that he will lose his job over this and that nothing will change, Niko stays persistent, strongwilled and stubborn. He has never imagined to ever face corrupt reality like this.

Besides this, the film author paints Niko's other personal qualities and issues: his family where he grew up, his circle of friends and the time they spend together, how he gets infatuated with a young female worker at the winery, who is airhead and unserious toward him, etc. With these and many other details, Otar Ioseliani presents the deeper portrait of the protagonist, so we can thoroughly determine through his actions how honest and sincere he is.

This film appeared after the "Epoch of Thaw" was dawn on Soviet film and culture. Therefore this film was an unusual event for the viewers, sort of sensation of its time. Almost nobody was making movies that didn't praise the soviet way of life, industry, agricultural, scientific or other type of achievement. The story of the film focuses on one particular situation in a specific institution that was probably happening elsewhere too. The goal of the film wasn't to point out the flaws of the Soviet Georgian ideology and political course. It only underlined that unfortunately, some facilities (the winery or some other place) had similar violations occurring and there was the need for the government to interfere accordingly.

Initially, the script was written for a mechanical equipment factory, but then Ioseliani changed it to a winery since winemaking is deeply-rooted in the Georgian culture. Growing vineyards and systems of making grape wine is an ancestral duty and grave responsibility for every farmer in the country. It transcends through generations, almost every Georgian family has its homemade wine, that's generally served when special guests are visiting. In the $\mathrm{XX}$ century winemaking in- creased in Georgia. New and bigger wineries were opened due to the great demand, high-quality product bottled and distributed to the stores. Although homemade wine is still a big part of the family culture, therefore wine is a self-defying aspect for the Georgian's identity, more so, Georgia is considered worldwide as a cradle and homeland of wine and winemaking culture.

By the enormity of this particular facility in the movie, Otar Ioseliani underlines the fragile tenderness of historic traditions of wine culture and how the morally grounded protagonist is trying to protect it. Niko is a modern young man, who sticks to his moral principles and doesn't compromise in doing the right thing; due to his mindset, he salvages bulk of shipment from falsification. His friend and coworker Otar, starting working there at the same time as the main hero, is a handsome young man, who differs from Niko's perspective. He is a sort of antagonist to Niko and urges him to drop the pursue of rightfulness and just cope with the way things are. Being indifferent towards the issue, all the other workers leave Niko the only righteous person standing in the whole factory as a protestant.

In 1966 the pre-screening process of the film had positive reviews from the Georgian Film Studio Artistic Board and then it was shown to the high ranking members of the Georgian government. It didn't go very successfully, the film was rejected and was denied release in the movie theaters. The government officials were opposed by the members of the film studio. The audience also had mixed feelings about the film - some deemed unnecessary pointing out imperfections of this sort. The film was considered against Soviet socialistic realism because the director should show only the good sides but the film showed the flaws. Neither the authorities nor the audience wanted to hear about it. This was healthy criticism. The different organizations demanded to scourge the director, some also demanded to physically destroy all the copies of the film, one letter stated that the protagonist is not depicted as a belligerent soviet adolescent, but as a passive, irresolute, spineless lad. In reality, this hero is a true nature man and tries to prove his truth. The film was deemed as unpromising, inauspicious work and a shame to the Georgian Soviet Socialistic Republic. The critics were banned to write positive reviews about it and it was put on the dusty shelf for years to come. 


\section{Arta cinematografică şi televiziunea}

In time, "Fallen Leaves" appeared in the movie theaters at last. It aroused debates and arguments. The main theme of the film is traditional: the conflict between the individual and society. The director drew a perfect picture of the evil dominating in his contemporary society. A part of film critics was delighted by the film, while others struggled against it. Otar Ioseliani used the principle of inclusion of documentary elements in a feature film and developed the story on the background of wine-producers' lives. He boldly described a community full of irresponsibility, selfishness, waste of the State property. The film is an outstanding example of critical realism and one of the masterpieces of the Georgian cinema.

"Fallen Leaves" was awarded two prizes at the Cannes International Film Festival in 1968: the Georges Sadoul Prize for the Best Debut and Prize of the International Federation of Film Critics (FIPRESCI).

The love of music led Otar Ioseliani to make the documentary film "Old Georgian Song" (1969), in which samples of the national folklore songs typical of the four different regions are presented. The film also includes some interesting pieces showing the ethnographical sides of Georgia in the ancient and middle ages; works of architecture, painting and applied arts.

In one interview, Otar Ioseliani said: "A man is responsible for his talent and before he leaves this world he must put at least one brick in a house to be built" [3, p. 108]. With this pathos, he, who struggled against false visibility in a film, made his new full-length fiction film "Once Upon a Time there was a Singing Blackbird" (1971). This phrase is taken from Georgian folk tales, since all tales begin with the words: "Once upon a time there was a singing blackbird, God is our mercy", and after such an introduction it was meant that the tale must have had a happy ending. Ioseliani did not follow such a line and presented a completely different story.

The film was based not on any literary material but dedicated to the memory of a young man who died at an early age and could not create anything significant in his life; he could not develop into a person. The literary script was called "The Musician" and the working title of the film was "Day by Day", by which Ioseliani indicated that the film would be a dramatic comedy or a comical drama. It depended on who and how looked at this unfolding story and how they perceived it.
The protagonist of the film is a talented musician who works in the orchestra of the Opera and Ballet Theater and plays the percussion instruments. However, his duty lasts only for a few seconds, because his involvement (music part) is at the end of any spectacle. So, he doesn't sit in the orchestra pit the whole time; he goes to visit different acquaintances or friends, spends time together, and at the last moment, he runs into the theater to perform his part.

Made in the usual strict documentary manner of narration, this film, like the previous one, deals with the relationship between the individual and society. The main character is a talented man, pretends to do something but everything is superficial. He can do anything: he can sing, play the piano, be a craftsman, is ready to help people in any way, but he can't find his place (and everyone else around him is busy with his favorite thing) and that's his problem, he doesn't even think about it. Despite his sociability, he is a strange film hero and not purposeful, like many others in other Soviet films. The film reflects the fact that there are such people in society and they need some help.

"One Upon a Time there was a Singing Blackbird" ends with the main character being hit by a bus on the street and he dies. This will end the life of such a man who is afraid to be alone. The notable metaphor is used in the film's finale when a watchmaker winds a clock with a single movement of his hand. It is exactly an impulse like that is necessary for the main character to order his life.

The Soviet cinema of that time was characterized by the appearance of such film personalities in the forefront, although by the end of the film they would inevitably be improved and made to work, and they would become exemplary young people. In this case, Otar Ioseliani chose differently - his hero died. In itself, such an approach has led to censorship dissatisfaction - the film shooting process has been banned. Added to this was the fact that Ioseliani could not shoot the film on time (which was to be completed by the end of 1970); so he was stripped off the filming equipment and banned from editing. The footage was then handed over to one of the editors who edited the film very poorly. Also, the film studio made tightened controls on each day of editing. Despite everything, Otar Ioseliani managed to edit the final version as he wanted and in 1971 the film was released on the screens. The filmgoers who were 


\section{Arta cinematografică şi televiziunea}

not accustomed to such works met the film with indifference. Many could not understand what its author wanted to say and why he made a film about such a hero. The attitude of film critics was also ambiguous: some critics liked it, some did not.

Later this film was awarded a prize of the Italian National Association of Filmmakers. It received other prizes too. In 1974 it was screened at Cannes Film Festival and the oldest master of French film Rene Clair congratulated Otar Ioseliani on his success.

The next and last full-length fiction film of Otar Ioseliani (for the Georgian period) is "Pastoral" (1975). Due to its title, this film should describe the idyllic existence of the village however, there is nothing idyllic in it; it is a complete irony. Its story is also simple at first glance - a quartet of musicians arrives in the village and settles in the family of a peasant to rehearse and prepare for the concert. The monotonous life of the local population is disintegrating against this background, which is full of ordinary people, however, this banality is accompanied by negative news and the director does not shy away from showing them. Indifference and inertia reign in this village which aggravates the monotony. The director used mostly non-professional actors. The main character was played by his daughter, Nana Ioseliani. With this film, the director showed that he was not only interested in the problems of the city but also interested in the modern village. Consequently, he painted a rather realistic and non-ideal picture of the village. Undoubtedly, there are several episodes from which it seems that individuals in this settlement violate both law and order. If the person is a specially arrived official from the city, who is a poacher, no one pays attention to it, but if this is a local ordinary person, he will be strictly warned or punished at least. "Pastoral" aroused debates and was soon banned for several years for the other Soviet Republics' screens (Except Georgia).

The Georgian film critic Irina Kuchukhidze wrote: "The film directing style of Otar Ioseliani is ideally suitable to the author's position and he flawlessly paints the world, which he foresees and feels in the difficult reality of our epoch. The film directing of Otar Ioseliani is another topic, his film laboratory is a fascinating sample of mastery and it is so functional that by the point of view of the contemporary film aesthetic arsenal stands above any changes of the weather. He is one of the few Georgian filmmakers who have not any incompleteness complex and are not at all skeptical of those trends, which sometimes, like meteors, turn over and blind a part of the film directors" $[4$, p. 74].

All three full-length fiction films of Otar Ioseliani can be considered a trilogy. Similar opinions circulate among Georgian film critics too, but the director himself never discusses them.

In the 70s, when in Tbilisi, in The Georgian State Theatrical Institute named after Shota Rustaveli (now - The Shota Rustaveli Theatre and Film Georgian State University) was opened a Film Faculty, Otar Ioseliani was invited there as a lecturer of film editing. They did not give him a post of a group supervisor because at that time he was acclaimed as a dissident. Many students (not only from this institution but from others too) attended his interesting lectures.

The Georgian film critics continue to research his oeuvre, analyzing its details and nuances. It is a good experience because Otar Ioseliani is very popular and representatives of different generations of scholars differently see and perceive his works. One of the film critics, Tata Tvalchrelidze noted: "Otar Ioseliani's diverse palette, an art of shot image, a culture of construction of the shot, a wonderful feeling of film stylistics, deep and comprehensive functional usage of the opportunities of the film art, without any external effects, serves for presenting the artistic truth on the screen. In the stories, seen from the outside as if objectively and diligently, without the intervention of the author in it, irony, light humor, sometimes parody and grotesque gradually emerge. Everything this founds peculiar poetry which is Otar Ioseliani's style, different from everyone else's" [7, pp. 46-47].

In a TV documentary film that was shot last year by the Georgian First Channel group dedicated to the celebration of Otar Ioseliani's eightyfive-year anniversary, the director underlined that he is a follower of the black and white film but now when there is a trend of the color film, he is forced to shoot only color movies. But every time he asks his cameraman to shoot such a color film, where the color should be soft and backstage and due to this, the film would be close to the traditional black and white movie. Also, he likes to make film editing by himself. It is a hard job for threefour months. He thinks that the film is only the author's work and not anybody else's. Besides he 
understands that such a film has no commercial success and could not make his director, producer or demonstrator rich. He is convinced that the author films have an audience despite everything. He has nostalgia for the black and white film.

When he makes a film, he believes that he has a like-minded person (or persons), that he is not alone, that someone needs his film. He calls filmmaking a craft and believes that every man must pay serious attention to it. He thinks that the audience does not like the falsity in the shooting techniques. Life for him is a wonderful phenomenon that is filled with both - truth and lie. He says that the film must be a healer.

He cannot imagine a man who is a filmmaker and thinks about what and how to shoot on the location. Every director must know everything before shooting, before reaching the shooting location. That's why he needs to have everything drawn on the storyboard.

Otar Ioseliani tries to restore the old film language, which was more telling than the contemporary one. He does not like to use a close up because it is a way for the director and the audience to enter the inner world of an actor and it is not interesting for everyone and, in his opinion, it does not mean anything. It is only presenting the personal features of an actor on the forefront and does not serve as a film character's expression. $\mathrm{He}$ pays less attention to the script because for him it is only a document for receiving a positive con- clusion to make a film from various controlling organizations.

In the second half of the 70s, Otar Ioseliani was invited to France. He went there and continued his creative work on a new stage.

By his attempt of disrobing the falsification, of showing the disadvantages of life, of calling for the rectification of the deficiencies, he is a rebel with a cause, a decent member of society, who is worried about all of the above-mentioned things.

\section{Bibliographical references}

1. Amiredjibi N. Filmmaker Otar Ioseliani. Tbilisi: Khelovneba, 2003 (in Georgian).

2. Dolidze Z. Georgian Film. Tbilisi: Raeo, 2004 (in Georgian).

3. Fomin V. The Intersection of parallel. Moscow: Iskusstvo, 1976 (in Russian).

4. Kuchukhidze I. The Georgian Period of Otar Ioseliani's Oeuvre. In the collection: "The Georgian filmmakers". Tbilisi: The Shota Rustaveli Theatre and Film Georgian State University, 2005 (in Georgian).

5. Sepiashvili O. Memory Symphony. Chronicles and Interludes of the Fate of Georgian Jews. New York: Xlibris, 2011.

6. Tsereteli K. The Famous Names. Tbilisi: Khelovneba, 1986 (in Georgian).

7. Tvalchrelidze T. Cinematic Searching. Tbilisi: Khelovneba, 1989 (in Georgian). 